\title{
European Transformations: Are the crises really over or is it just the end of their beginning?
}

\author{
Hauke Brunkhorst/ Monika Eigmüller/ John Erik Fossum
}

It used to be the case that most scholars engaging with the law, the politics and the economics of European integration assumed that crises, while perhaps de-stabilizing the European Communities in the short run, were bound to foster the consolidation and advancement of the "cause" of European integration in the long run. ${ }^{1}$ After all, the European Union was the stepchild of the two major wars of the XXth century and of the tumultuous inter-war period. By the same token, the European Communities consolidated and grew through (perhaps even thanks to) the different series of major crises of the subsequent period: the Cold War, the monetary and economic crises of the 1970s, and the fall of the Berlin Wall. To put it differently, the particular, sui generis, character of the European Communities was understood as encompassing a close relationship between crises and integration. So much so that crises were reinterpreted from their mainstream meaning as existential traumas that by virtue of their severity would require serious reconsideration of the purpose and means of integration ${ }^{2}$ to moments at which the usefulness and purposefulness of the Communities would become more apparently evident. This goes a long way towards explaining why EU studies reacted rather slowly in the aftermath of the 2007 crises. Why hurry if at the end of the tunnel a rejuvenated Union appears? Furthermore, after the initial shock a sort of theoretical complacency appears to have re-emerged which seems inclined to downplay the deleterious implications of the crises. The implication is "to do crises" as if they were just another fashionable subject. The upshot is a form of theoretical amnesia: to assume that whereas the crises challenged the law, the politics and the economics of the European Union and its Member States, they carry no implications for the methodological and substantive premises of the legal and politico-scientific analyses of the European Union.

\footnotetext{
${ }^{1}$ Among the few dissenting voices were (some) historians, who were not only keen to take a longer view, but whose professional acumen impressed upon them the need to remember the serious difficulties that the Communities had gone through, especially in the early seventies.

2 The word crisis comes from the Greek term krisis meaning division and "decision" in the sense of reaching a crucial point that would tip the scales."(Koselleck and Richter 2006:358) In a social science context, we may understand crisis as a situation where there is a perceived threat to the core values or life-sustaining functions of a social system that requires urgent remedial action in uncertain circumstances (Rosenthal, Charles and 't Hart 1989, cf Chrisensen et al 2014).
} 
The authors of the articles that make up this special section share the view that it is time that European legal and politico-scientific scholarship take crises in general, and very especially the manifold and overlapping set of crises that Europe is presently undergoing, seriously. It is time to drop any form of determinism, to overcome the "Whig" reading of the history of European integration, and delve more deeply into the structural causes and structural implications of the crises; indeed, it is time to take seriously the breadth, depth and scope of the crises, and the extent to which what is indeed a clear rupture with the legal, political and social constitutional model of the Democratic and Social state is becoming a new form of government unto itself; the main implication being that we need to be open to question the way in which we go, as legal and social science scholars, about researching. This was the spirit of the workshop in which the articles were first presented, this has been the spirit in which they have been edited for their publication here, and this is the spirit in which they are now presented to the reader of the European Law Journal.

All contributions share the view that crises are not mere growth pangs. Muddling through by means of a resort to some form of technocratic constitutional engineering is no longer a viable option. It is indeed telling that the Lisbon Treaty reform, the epitome of secretive back-room reforms of the way in which power is organized in Europe, was heralded in 2009 as a resounding success, providing Europe with the reforms it needed for the next fifty years, is now regarded as a major blunder. Lisbon not only failed the mark (by far) of producing the framework for a stable European political order, but was intentionally produced in vitro, in the relative absence of public input. The ink on which the Treaty copies were printed was barely dry when the financial ticking bomb of a long decade of growth of fictitious capital exploded. By the end of 2009, however, the mood was still celebratory: economic and monetary union, impersonated by the euro, were heralded in their tenth anniversary by European institutions as having provided the Eurozone cover from the massive storm in the dangerous waters of the world economy. The selfcongratulatory tone went silent, though as the fiscal asphyxia of Greece first, and then of most of the Eurozone periphery hit in a matter of weeks. The fiscal crises of Hungary and Latvia (2008), Romania (2009), Greece (2010, 2012, 2015), Ireland (2010), Portugal (2011), Spain (2012), Cyprus (2013) revealed not only the structural defects of economic and monetary union, but the very structural defects of the socio-economic model that underpinned and propelled the single market as the realm where the divine rights of property would be reaffirmed. Since then, the European Union has exhibited a manifest lack of ability to tackle major policy challenges, 
resulting in the multiplication of crises. Not least of which the massive humanitarian crisis resulting from the interplay of a marked increase in the numbers of forced migrants reaching Europe, the inadequacy of the framework under which European states combine their migration and refugee policies, and a political backlash fed by growing inequalities and poverty rates, which render the "two third societies" of the 1980s palatable in comparison. The success of politicians flirting with openly xenophobic ideas, reminiscent of the darkest hours of Europe's past is revealing not only of the dangers lurking in the future, but of the extent to which mainstream political parties have abandoned a commitment to a meaningful politics that takes seriously the lives and fates of their voters, escaping instead into empty discourses insufficiently attentive to voters and broader challenges.

The most obvious, but not always the easiest task, is that of providing an accurate and comprehensive diagnosis of the crises. The urgency of action calls for quick analyses, but the uncertainties surrounding crises call for reflective distance, to avoid falling into crisis-induced forms of group-think. ${ }^{3}$ This is why we may take several steps backwards before advancing decidedly. In the opening article, Gurminder Bhambra suggests that we need to take several steps back, and look to the present crises through the lenses of the long historical shadow of Europe's past. It is revealing, but not surprising, that this past has been suppressed not only regarding the financial, economic and fiscal crises (when it has been invoked, scandal has ensued) but also regarding the humanitarian crisis which is usually referred to as the refugee crises. Still, the clear surge in the number of forced migrants reaching Europe is not only directly related to European foreign policy decisions and non-decisions (from the several Iraq wars to the invasion of Libya in 2011), but to Europe's imperial and colonial past. ${ }^{4}$ Such a past has played a

${ }^{3}$ Crises are similar to wicked problems, which are among other things marked by a distinct relationship between problem understanding and problem resolution, which dispels rational problem handling through ruling out a necessary search for and weighing of the relevant options: "To find the problem is --- the same thing as finding the solution; the problem can't be defined until the solution has been found. The formulation of a wicked problem is the problem! The process of formulating the problem and of conceiving of a solution (or re-solution) are identical, since every specification of the problem is a specification of the direction in which a treatment is considered."(Rittel and Webber 1973:161)

${ }^{4}$ Some political actors and pundits, not least in Eastern Europe, have argued that only some European states, not all of them, were colonial powers. While imperial nations may have duties towards the colonised, they do not have them. That is a rather disingenuous argument, contradicted by the simultaneous protestations of vintage Europeanness of the same political 
major role in shaping the understanding of personal statuses in Europe, thus affecting the law and politics of citizenship and membership in Europe as a whole. A politics of 'selective memory' downplays the critical role of 'race' as the constructed category that served (and unfortunately, keeps on serving) as a basis for social exclusion. Talk about 'cosmopolitan Europe' or, for that matter, of Europe as 'force civilisatrice' is bound to be cheap talk until Europe (and the European Union) confronts the dark legacies of the colonial past. If Bhambra takes us back in time, Marcelo Neves's contribution engages with geographical distance in his analysis of the very grammar and narrative of European constitutional law. What Europeans usually regard as an exclusive trait of the European constitution, its transnational character, seems to Neves a defining trait of modern legal systems, as it becomes extremely frequent that two or more legal orders overlap in the legal disciplining of underlying issues of constitutional relevance. Seen from the other side of the mirror, so to say, trans-constitutionalism is however a far from necessarily benign development. Neves insists that trans-constitutional law, as much as any form of law, is not only related to power, but may be a vehicle of power and domination. European legal scholars and political scientists may have been blessed enough to miss power, but power is unmissable when the European Union is looked from the outside. Consequently, analyses of trans-constitutional law have indeed to take seriously that uneasy relationship between law and power, instead of assuming (as is far from infrequently the case) that European law has finally managed to square the circle and eradicate domination. Monika Eigmüller proposes to the reader to take disciplinary distance and look at the transformation of Europe through the crises from a sociological perspective. It has tended to be assumed in the European Communities, and for that matter, in all polities, that social integration precedes institutional and systemic integration, so that the latter will necessarily precede the former. By the same token, social disintegration renders futile (and dangerous) the creation of new common institutional structures, decision-making processes and substantive norms. The actual pattern of transformation of European societies confounds the neatness of such assumptions. On the one hand, we can observe a loss of trust and confidence in the EU, which has resulted in challenges to the political and legal authority of European institutions. On the other hand, citizens have kept on expressing their commitment to European integration, and, more decisively, considerable parts of the population have acted in solidaristic fashion (one should not downplay the civil society expressions of

actors and pundits. Paraphrasing the Polish born Joseph Conrad, all Europe contributed to the making of Kurtz, and not only France, Britain or for that matter, Belgium. 
concrete solidarity during the fiscal or refugee crises). That may point to the massive difference that the proper functioning of institutions makes in shaping the relationship between social and system integration. A form of everyday Europeanism seems to have emerged after decades of formal integration, fostering patterns of solidarity largely detached from the European institutional-legal structure. Paradoxically, then, many of the sociological foundations for a pluralistic European constitutional order are already there, but the European Union that emerged out of the crises is not very capable of harnessing this, hence situating the everyday Europeanism on very shaky foundations.

Critical distance is a preliminary step to in-depth engagement with four key aspects of the crisisridden European Union, revealing how power is actually organized in Europe nowadays: the "structural constitution" (institutional structure and decision-making processes), the "vertical constitution" (dealing with the relationship between levels of government), the "substantive constitution", and the "changing" constitution. Fritz W. Scharpf focuses on the many institutional constraints that hem in the EU's capacity for democratic political action. He underlines that the crisis-induced shift in decisional gravity towards asymmetric and informal intergovernmentalism is unlikely to help the Union overcome the traps built into its institutional structure and decision-making processes. Scharpf proposes a range of measures bent on removing or confining constraints on democratic decision making at both the European and national levels. Hauke Brunkhorst focuses on the false promise of constitutionalization and what are the proper sociological and economic underpinnings of European law. More specifically, what Brunkhorst refers to as the false promise of European constitutional law is equality through markets; at the same time the EU has sought to balance redistribution and recognition. He takes as his point of departure the important fusion of democracy and social solidarity that marks Europe's post-war past, has animated all normative ideals of Europe's citizenship regime, and yet is now what is hanging in the balance. As Europe has embarked on the track of (socially) regressive reformism, it has proven itself no longer capable of addressing vertical inequalities, while at the same time maintaining important advances of progressive reformism in terms of emancipation from horizontal inequalities. The upshot is that social criticism and the idea of social egalitarianism are left behind. Without a proper return to these ideas a democratic renewal of Europe will be impossible. Jonathan White links his diagnosis of the Union's present conundrums to the manner in which the EU has veered from its historical path. In doing so he points to the centrality 
of past commitments. Fidelity has been cast as a central spur to developing the EU along a fixed path, as set out in established commitments. In the EU context, as White notes, there is a close intellectual affinity between this understanding of change and the implementation of a certain socio-economic policy programme (rather close to a peculiar mix of ordo-liberal and neoliberal views). White stresses that change as fidelity is rather different from incrementalism, and indeed leaves considerable space for change (indeed, not infrequently, radical change). Still, the present crises have ushered in a new mode of emergency politics with invocations of necessity that are quite inimical to revisionism, even if occasionally the substantive goals are not at odds with those pursued through revisionism. John Erik Fossum focuses on the legal and political mediation of the tension between self-rule and shared rule at the core of European integration. Fossum notes that European scholars of a legal and political bent have largely shirked away from the core concerns that lie at the heart of federal arrangements: power, membership and borders. EU studies have oscillated between an overly strong commitment to centralization, assuming the Union would become a 'normal' state in the long run (an assumption that still lurks in the depths of the primacy principle), and descriptions of the Union as either sui generis or as a "multilevel polity'. These perspectives are however not well-equipped to address the theoretical questions that the EU brings up. In discussing the EU from a federal perspective, we need to recognize the Union's lack of internal homogeneity, the different characters and nature of the different heads of which it is made up (the different institutional structures, decision-making processes and substantive norms making up the single market, economic and monetary union, security and foreign policy and the other 'bits and pieces'). Drawing on a comparison with Canada, Fossum shows that establishing a viable democratic federation requires both more and less integration.

Finally, amidst the gale force winds that have shaken the foundations of European integration, law is said to remain a safe foundation, indeed a safe harbor. Weiler's recent reminder of the speed at which the belief in formal legality can be eroded (especially when its currency is unwisely spent) seems to have escaped attention in many quarters. Poul Kjaer's contribution pushes the argument forward by considering how the transformation of European integration, very especially but not exclusively from the crises, has altered the grammar of European law, with profound implications for the efficiency and legitimacy of the transnational legal order. In Kajer's view, the 'turn to governance' implies an erosion of the distinction between public and private realms, and increasingly challenges the normative integrity and functional capacity of 
law. This development has been further reinforced by the new post-crisis legal and institutional architecture of the EU as it implies the emergence of a 'dual Union' partly based upon formality and partly upon informality and an increased suspension of open-ended democratic decisionmaking.

It seems to us that all articles provide an account of what remains a critical situation. From different perspectives, they all help to clarify what the crises have done to the European Union, and we may add, what the European Union professional community has and has not done to the crises. None of the papers provides the ready-made, key-in-hand solutions that once were characteristic of policy papers, and now are compulsory fare in the races to get funding. Instead, the reader will find tentative, experimental suggestions for changes and radical reforms of the Union within and beyond its present constitutional frame, presented as what they can, at best, be: scholarly reflections aimed at self-critical engagement with the agenda and contents of research, which may serve to initiate rather than foreclose, public debate.

Last but not least we have to thank the German Research Foundation (DFG) for generously funding the conference on the critical situation of the EU at European University Flensburg in May 2016, where earlier versions of these articles were first discussed. 